\title{
Management of obesity with integrated Ayurveda and Yoga intervention: A case report
}

\author{
Case Report
}

\section{Harish Deshpande $^{*}$, Sarganacharya $S \mathbf{V}^{\mathbf{2}}$}

1. PhD Scholar, 2. Professor, Department of Swasthavritta, Parul Institute of Ayurveda, Parul University, Vadodara, Gujarat.

\begin{abstract}
Obesity is the disease of nutritional deficiency which leads to abnormal growth of adipose tissue resulting in an increase in the body weight to the extent of $20 \%$ or more of standard weight for the person's age, sex, and height. Obesity is one side of the double burden of malnutrition, and today more people are obese than underweight. In Ayurveda Obesity is classified under santarpanjanya rogas and ashtaninditiya purusha by Acharya Charaka. Ayurveda attributes concept of Dosha, dhatus and Mala in which any vikriti in any of dhatus, pramanatah or gunatah then it firmly affects both body and mind. Yoga and Ayurveda both spring as a greater part of spiritual and mental aspect of treatment. Considering all these factors this study is carried out to understand cause, cause effect relationship as well as treatment. In this case study patient was treated with Udwarthana, Shodhana and Shamana chikitsa, also advised Ahara (scheduled diet) and Vihara (life style modification) for the management of obesity. This showed a significant change in anthropometric measurement.
\end{abstract}

Key Words: Obesity, Sthoulya, Ayurveda, Yoga.

\section{Introduction}

In present era, every individual is hindered after life goal, aiming for sedentary lifestyle. Unfortunately, leading a burden on lifestyle disorders. These are increasing vigorously worldwide. It is a complex, multifactorial, and largely preventable disease. By 2030 an estimated $38 \%$ of the world's adult population will be overweight and another $20 \%$ will be obese.(1)

Obesity is defined quite simply as excess body weight for height, but this simple definition reveals an etiologically complex phenotype primarily associated with excess adiposity, or body fatness, that can manifest metabolically and not just in terms of body size.(2-6) Obesity is expressed in terms of body mass index (BMI). The distribution of fat induced by the weight gain affects the risk associated with obesity and the kind of disease that results. It is useful therefore, to be able to distinguish between those at increased risk as a result of "Abdominal fat distribution" or "android obesity", in which fat is more evenly and peripherally distributed around the body.(7) In Ayurveda obesity can be understood as 'Sthoulya' which is derived from Sthoola

\section{* Corresponding Author:}

\section{Harish Deshpande}

Associate Professor,

Department of Swasthavritta,

SVM Ayurvedic Medical college, Ilkal.

Karnataka. India

Email Id: drharishdeshpande@gmail.com which means as bulkiness which increases the weight of tissue. It is the condition where there is a increase in the body fat which is vikruta medodhatu vriddhi. Hence, it is classified under Ashtaninditiya Purusha by Acharya Charaka(8) in his treatise called Charaka Samhita. Ayurveda also point up Sthoulya as, Medadhatu pradoshaja vikara, Kaphadosha pradoshaja vikara, Bahudosha avasta, Santarpanjanya vikara.

Treatment aims at nidana parivarjana which is basic line of management followed by samshodana and karshana by giving lekhana basti, mrudu anulomana, rooksha basti, shamana chikista by giving aushadi dravyas internally. The definition of health in Ayurveda is as the equilibrium state of doshas and dushyas along with mental, sensory and spiritual happiness and pleasentness.(9)

Yoga is the spiritual branch of treating various ailments. Etymology of yoga states that which unites is known as yoga. That which brings about union of soul with God is yoga. According to Patanjali yoga sutra Yoga is cessation of mental modifications or citta vrittis due to mind, intellect and ego. Ayurveda states the concept of prajnaparadha i.e intellectual errors in which a person indulges various activities knowingly or unknowing causing other health aliments. It also emphasize codes and conduct called as sadvrutta, Achara Rasayana and Yoga which helps in healthy state of mind and thereby helps in prevention of psychological, somatic and psychosomatic disorders. (10). 
Harish Deshpande et.al., Management of Obesity with integrated Ayurveda and Yoga intervention: A case report

Aims and objectives

1. To understand nidana, poorvarupa, rupa, upashaya and anupashaya of sthoulya in detail.

2. To understand role of Ayurveda and Yoga in the management of Sthoulya.

3. To understand Obesity in detail.

\section{Case study}

A male aged 34years, hailing from ILKAL working in private company as an Engineer, due to the excess intake of Madhura(Sweet), Snigdha ahara(Unctuousness food), like junk foods(Oily/fast foods) bakery products, Atimamsa Sevana and Vihara like Avyayama (lack of exercise), Divaswapna (Daysleep) the clinical features like excess fat in the region of abdomen, buttocks and breast, due to which the body weight and BMI is increased since last 3 years.

Associated complaints: Heaviness in the body, Excessive hunger, thirst and sweating.

Past Medical history: No History of Diabetes Mellitus/ Hypertension/Thyroid/Asthma/Operative procedures.

Treatment history: No history found

Family history: Mother is Obese

Personal History: Patient having the history of intake of alcohol since last 10 years.

Table 1: The International Classification of adult Obesity, underweight and overweight according to BMI.(11)

\begin{tabular}{l|l|l|} 
Classification & \multicolumn{2}{|c}{ BMI $\left(\mathbf{k g} / \mathbf{m}^{2}\right)$} \\
& $\begin{array}{c}\text { Principal } \\
\text { cut-off points }\end{array}$ & $\begin{array}{c}\text { Additional } \\
\text { cut-off points }\end{array}$ \\
\hline Underweight & $<18.50$ & $<18.50$ \\
\hline $\begin{array}{l}\text { Severe } \\
\text { thinness }\end{array}$ & $<16.00$ & $<16.00$ \\
\hline $\begin{array}{l}\text { Moderate } \\
\text { thinness }\end{array}$ & $16.00-16.99$ & $16.00-16.99$ \\
\hline Mild thinness & $17.00-18.49$ & $17.00-18.49$ \\
\hline Normal range & $18.50-24.99$ & $18.50-22.99$ \\
\hline Overweight & $\geq 25.00$ & $23.00-24.99$ \\
\hline Pre-obese & $25.00-29.99$ & $\begin{array}{l}25.00-27.49 \\
27.50-29.99\end{array}$ \\
\hline Obese & $\geq 30.00$ & $\geq 30.00$ \\
\hline Obese class 1 & $30.00-34.99$ & $30.00-32.49$ \\
\hline Obese class 2 & $35.00-39.99$ & $\begin{array}{l}35.00-37.99 \\
37.50-39.99\end{array}$ \\
\hline Obese class 3 & $\geq 40.00$ & $\geq 40.00$
\end{tabular}

\section{Materials and Methods}

Data is collected from the OPD and IPD of SVM Ayurvedic Medical College and Hospital ILKAL. Atarpana Chikista was adopted and results were assessed before and after treatment.
Table 2: Anthropometry measurements and personal history observed before treatment.

Blood Pressure Pulse rate

$120 / 80 \mathrm{~mm}$ of $\mathrm{Hg}$

Height

Weight

Body Mass Index

Chest Circumference

$82 \mathrm{bts} / \mathrm{min}$

$150.2 \mathrm{cms}$

$86.5 \mathrm{~kg}$

$38.4 \mathrm{~kg} / \mathrm{m}^{2}$

$110 \mathrm{cms}$

Abdomen Circumference

$115 \mathrm{cms}$

\begin{tabular}{c|c} 
Mid Arm Circumference & Rt hand $-34 \mathrm{cms}$, \\
& Lt hand $-35 \mathrm{cms}$ \\
Mid Thigh Circumference & Rt leg $-62 \mathrm{cms}$, \\
& Lt leg $-63 \mathrm{cms}$
\end{tabular}

Waist Circumference

$116 \mathrm{cms}$

Hip Circumference

$135 \mathrm{cms}$

Ahaara
Vihaara
Appetite
Bowels
Micturation
Sleep
Habits

Vegetarian diet Avyayama, Divaswapna Good

Regular, normal in consistency, twice a day

Normal, 3-4 times/day, 1-2 times at night. Good

Excessive Oily foods, Cold

Drinks and Bakery products

Table 3: Physical Examination which signifies about bulky appearance, endomorphic built of patient.

\begin{tabular}{|c|c|}
\hline Appearance & Bulky \\
\hline Built & Endomorphic \\
\hline Nourishment & Well nourished \\
\hline Gait & Normal \\
\hline Pallor & Absent \\
\hline Icterus & Absent \\
\hline Cyanosis & Absent \\
\hline Clubbing & Absent \\
\hline Edema & Absent \\
\hline Lymphadenopathy & Absent \\
\hline
\end{tabular}

Table 4: Systemic Examination

Cardio Vascular System(CVS) $\quad$ S1, S2 heard

Respiratory System(RS)

AEBE

Central Nervous System(CNS) Well oriented

Per Abdomen(P/A)

Soft, No organomegally

\section{Investigational history}

Table 5: History of Laboratory Investigations:

\begin{tabular}{|l|l|}
\hline $\mathrm{Hb} \%$ & $11.3 \mathrm{gm} \%$ \\
\hline WBC & 9600 cells $/ \mathrm{cu} \mathrm{mm}$ \\
\hline E.S.R & $34 \mathrm{~mm} / \mathrm{hr}$ \\
\hline Neutrophils & $56 \%$ \\
\hline Lymphocytes & $44 \%$ \\
\hline Monocytes & $0 \%$ \\
\hline Eosinophils & $1 \%$ \\
\hline Platelets & $3.76 \mathrm{lakhs} / \mathrm{cu} \mathrm{mm}$ \\
\hline RBC Count & $4.58 \mathrm{millions} / \mathrm{cu} \mathrm{mm}$ \\
\hline F.B.S & $78.1 \mathrm{mg} / \mathrm{dl}$ \\
\hline Blood urea & $15.8 \mathrm{mg} / \mathrm{dl}$ \\
\hline Serum Creatinine & $0.8 \mathrm{mg} / \mathrm{dl}$ \\
\hline
\end{tabular}


Table 6: Haemogram report

\begin{tabular}{|l|c|}
\hline P.C.V & $36.2 \%$ \\
\hline M.C.V & $79.1 \mathrm{fL}$ \\
\hline M.C.H & $24.7 \mathrm{Pg}$ \\
\hline M.C.H.C & $31.6 \%$ \\
\hline RDW & $47.8 \mathrm{FI}$ \\
\hline
\end{tabular}

Table 7: Lipid Profile

\begin{tabular}{l|r} 
Total Cholesterol & $182.2 \mathrm{mg} / \mathrm{dl}$ \\
\hline H.D.L Cholesterol & $84.2 \mathrm{mg} / \mathrm{dl}$ \\
\hline L.D.L Cholesterol & $85.2 \mathrm{mg} / \mathrm{dl}$ \\
\hline Triglycerides & $216.2 \mathrm{mg} / \mathrm{dl}$ \\
\hline VLDL & $45.2 \mathrm{mg} / \mathrm{dl}$
\end{tabular}

USG Abdomen and ECG showed Normal study, there were no significant changes seen.

Table 8: Dashavidha Rogi Pareeksha

\begin{tabular}{|l|c|l|}
\hline Prakriti & Dwandwaja, Vata Kapha & \\
\hline Vikrita Dosha & Kapha & \\
\hline Dushya & Rasa, Mamsa and Meda & \\
\hline Sara & Madhyama & \\
\hline Samhanana & Madhyama & \\
\hline Satva & Madhyama & \\
\hline Aahara Shakti & Abhyavahara & Pravara \\
\hline Vyayama Shakti & Jaranasakthi & Pravara \\
\hline Satmya & Avara & \\
\hline Vaya & Madhyama & \\
\hline Pramana & Madhyama & \\
\hline
\end{tabular}

Table 9:Astasthana Pareeksha

\begin{tabular}{|l|c|}
\hline Nadi & Prakruta \\
\hline Mala & Niraama mala, prakrita \\
\hline Mootra & Prakrita \\
\hline Jihva & Aliptata \\
\hline Sabda & Prakrita \\
\hline Sparsha & Anushna Sheeta \\
\hline Drik & Prakrita \\
\hline Aakruti & Sthoola \\
\hline
\end{tabular}

\section{Samprapti of Sthoulya(12)}

Hetusevana (Kaphakara madhura ahara, avyayam, divaswapna)

Vikrut medo vruddhi (increase in vitiation of meda dhatu)

Srotorodha (Obstruction in srotas)

Vatadosha takes vimargagamana

Vatadosha gets koshtashrita and increases agni bala

Stimulates fast digestion and assimilation

I

Increased intake of food

Vikrutamedhautpatti

-

Sthoulya

\section{Table 10: Samprapti Ghatakas}

\begin{tabular}{l|c}
\hline Udbhava Sthana & Amashaya \\
\hline Vyaktasthana & Sarva Shareera \\
\hline Adhistana & Medo dhatu \\
\hline Roga marga & Bahya \\
\hline Agni & Teekshnagni \\
\hline Dhatwangni & Manda \\
\hline Dosha & Kapha and Vata \\
\hline Dushya & Rasa, Mamsa and Medo \\
\hline Srotas & Medovaha, Rasavaha \\
\hline Sroto dusti & Sanga \\
Sadhya Asadhyata & Krichra Sadhya \\
\hline
\end{tabular}

All the examinations done and reported in the above mentioned tables, the disease was understood and diagnosed as Sthoulya. Based on the patient's Agni and prakruti the treatment was planned. Initially started with udwartana,(13) udwarthana churna contains Kulatha- 4 parts, Yava -4 parts, Triphala -2 parts, Mudga - 1 part, Methika - 1 part, Sarshapa $-1 / 4^{\text {th }}$ part. Followed by sadhyo virechana along with shamana aushadi were advised. Pathyaahara and yogasanas were advised daily along with other treatments. Considering Ashtavidha and Dashavidha pariksha bhavas the following treatment was planned.

\section{Table 11: Chikista Siddhanta} Pathya ahara (Diet food) (14-16)

7 am Kulatha/Mudga (100g) yusha (gruel)

$10 \mathrm{am}$ Takra $(200 \mathrm{ml})$

$1 \mathrm{pm} \quad$ Yava Chapati (2) $-50 \mathrm{~g}$

Leafy vegetable- spinach / fenugreek/ amaranth $(100 \mathrm{~g})$

Vegetable - beans/ cabbage/ash gourd /tomato $(100 \mathrm{~g})$

Root and tuber - carrot/ knolkhol (25g)

$4 \mathrm{pm}$ Mixed salad (100g)

$7 \mathrm{pm} \quad$ Yava Chapati (2) $-50 \mathrm{~g}$

Leafy vegetable- spinach / fenugreek/ amaranth $(100 \mathrm{~g})$

Vegetable - beans/ cabbage/ash gourd/tomato (100g)

Root and tuber - carrot/ knolkhol(Wild cabbage) (25g)

$8 \mathrm{pm} \quad$ Skimmed off milk $(200 \mathrm{ml})$

Table 12: Treatment Schedule 31-10-2020 to 18-11-2020

\begin{tabular}{|c|c|c|}
\hline ays & Treatment & Observation \\
\hline-8 & $\begin{array}{l}\text { 1. Udwarthana and Bhaspa } \\
\text { sweda } \\
\text { 2. Tab Navaka Guggulu } 2 \mathrm{BD} \\
\text { (A/F) } \\
\text { 3. Varunadi Kashaya }(10 \mathrm{ml} \\
\text { with warm water B/F) } \\
\text { 4. Yoga and Pranayama } \\
\text { 5. Pathyahara. }\end{array}$ & $\begin{array}{l}\text { - } \text { Bowel - } \\
\text { Passed } \\
\text { - Appetite- } \\
\text { Good } \\
\text { - Micturation - } \\
\text { Passed } \\
\text { - Sleep - } \\
\text { Sound }\end{array}$ \\
\hline
\end{tabular}


Harish Deshpande et.al., Management of Obesity with integrated Ayurveda and Yoga intervention: A case report

\begin{tabular}{l|l} 
Treatment & Observation
\end{tabular}

1. Udwarthana and Bhaspa sweda

- Bowel Passed

Day 2. Cap Decrin Plus 2 BD (A/

9-16 F)

3. Asanadi Kashaya $(10 \mathrm{ml}$ with warm water B/F)

4. Yoga Pranayama

5. Pathyahara

Treatment

- Appetite -

Good

- Micturation -

Passed

- Sleep - Sound

Observation

\begin{tabular}{l|l} 
Day & Snana followed by \\
$\mathbf{1 7}$ & SadhyoVirechana with Trivruth
\end{tabular}

17 lehya-60gm with Draksha

Kashaya $150 \mathrm{ml}$.

Day Discharged

18

Table 13: Yogasanas advised during treatment(17) Asanas

Names

(Total duration:70 minutes)

Warm up exercises (10

minutes)

Surya Namaskara(15

minutes)

Standing posture asanas (10

minutes)

Sitting posture asanas (10

minutes)

Prone posture asanas (10

minutes)

Pranayama (15 minutes)

Hand to ankle rotation loosening exercise 10 rounds

Ardha Chakrasana, Trikonasana

Matsyendrasana, Vajrasana

Pavanamuktasana

Bhastrika

Bhramari

\section{Table 14: Evaluation of Anthropometry changes} before and after treatment

\begin{tabular}{l|c|c|}
\multicolumn{1}{|c|}{ Observation } & $\begin{array}{c}\text { Before } \\
\text { Treatment }\end{array}$ & After Treatment \\
\hline Weight & $86.5 \mathrm{~kg}$ & $81.1 \mathrm{~kg}$ \\
\hline Body Mass Index & $38.4 \mathrm{~kg} / \mathrm{m}^{2}$ & $36 \mathrm{~kg} / \mathrm{m}^{2}$ \\
\hline $\begin{array}{l}\text { Abdomen } \\
\text { Circumference }\end{array}$ & $115 \mathrm{cms}$ & $110 \mathrm{cms}$ \\
\hline $\begin{array}{l}\text { Mid Arm } \\
\text { Circumference }\end{array}$ & $\begin{array}{c}\text { Rt hand }-34 \mathrm{cms}, \\
\text { Lt hand }-35 \mathrm{cms}\end{array}$ & $\begin{array}{c}\text { Rt hand }-30 \mathrm{cms}, \\
\text { Lt hand }-31 \mathrm{cms}\end{array}$ \\
\hline $\begin{array}{l}\text { Mid Thigh } \\
\text { Circumference }\end{array}$ & $\begin{array}{c}\text { Rt leg }-62 \mathrm{cms}, \\
\text { Lt leg }-63 \mathrm{cms}\end{array}$ & $\begin{array}{c}\text { Rt leg }-57 \mathrm{cms}, \\
\text { Lt leg }-59 \mathrm{cms}\end{array}$ \\
\hline $\begin{array}{l}\text { Waist } \\
\text { Circumference }\end{array}$ & $116 \mathrm{cms}$ & $109 \mathrm{cms}$ \\
\hline $\begin{array}{l}\text { Hip } \\
\text { Circumference }\end{array}$ & $135 \mathrm{cms}$ & $129 \mathrm{cms}$ \\
Waist/Hip Ratio & 0.85 & 0.84
\end{tabular}

Table 15: Evaluation of Lipid profile changes before and after treatment

\begin{tabular}{l|c|c|}
\hline Total Cholesterol & $212 \mathrm{mg} / \mathrm{dl}$ & $180 \mathrm{mg} / \mathrm{dl}$ \\
\hline $\begin{array}{l}\text { H.D.L } \\
\text { Cholesterol }\end{array}$ & $50.1 \mathrm{mg} / \mathrm{dl}$ & $84.3 \mathrm{mg} / \mathrm{dl}$ \\
\hline $\begin{array}{l}\text { L.D.L } \\
\text { Cholesterol }\end{array}$ & $132.2 \mathrm{mg} / \mathrm{dl}$ & $115.1 \mathrm{mg} / \mathrm{dl}$ \\
\hline Triglycerides & $199.3 \mathrm{mg} / \mathrm{dl}$ & $150.1 \mathrm{mg} / \mathrm{dl}$ \\
\hline VLDL & $45.2 \mathrm{mg} / \mathrm{dl}$ & $25.3 \mathrm{mg} / \mathrm{dl}$ \\
\hline
\end{tabular}

Probable mode of action of therapeutic procedures, Yogasanas and pathyaahara

In the study we have taken udwartana and virechana as therapeutic procedures in which udwartana followed by bhaspa sweda relieves srotorodha and helps in liquification of doshas. The drugs used in udwartana allievates kapha, vata, Ama and Medha(fat). They possess ruksha guna which scrapes fat tissue in body and enhance free transportation of nutrients and other essential to all tissues of the body. It also rejuvenates cells and recharges it for better functioning. Virechana with Trivrit Lehyam with draksha kashaya causes Medoharana. $(18,19)$

Virechana is one among Panchakarma. The predominance of prithvi and jala mahabhuta in virechaka dravya will have natural tendency to move downwards and thus they can induce virechana kriya. A quality of virechaka dravya includes sushna, tikshna, sukshma guna having capacity of vyavayi and vikasi which brings doshas from shakha to koshta and induce virechana.

Navaka Guggulu has Katu-Kashaya Rasa, Laghu-Ruksha-Tikshna Guna, Ushna Virya and Kapha Vata Shamaka, Dipana Karma, among them 70\% have Pachana and 50\% have Yakriduttejaka, Karshana, Meda-Sneha-Kleda Shoshana and Srotovishodhana Karma which all have opposite action on Kapha Dosha as well as Meda Dhatu. (20)

Each capsule of Decrin Plus contains Amrutadi Gugggulu 250mg, Navaka Guggulu $60 \mathrm{mg}$, Shudda Shilajitu 30mg, Aghada 60mg, Bhavana with Guduchi, Punarnava \& Gokshura Swarasa. (21)

Asanadi kashaya having tikta predominance kashaya rasa reduces kapha dosha as it causes dryness; regularizes the metabolism (Deepana-Pachana); dries up medas (medoshoshaka); uses up the fat/moisture (kleda shoshaka/kleda upayokta); leans the body (karshana). The combined effect is seen on Medodosha. $(22,23)$

Varunadi Ganahas has Kaphaghna and medoghna properties. So, it is most appropriate to select this Varunadi Kashaya for doing lekhana karma in Sthoulya.(24)

In modern parlance, it may act like catalytic agent which converts saturated compounds into unsaturated one in the form in which they are more reactive. Shodhana therapies are mild irritant to stomach and intestinal mucosa to cause inflammation. Due to this permeability of the membrane changes.(25)

Asanas advised promotes strengthens abdominal muscles and also helps in reducing abdominal fat. Dravyas used in pathya kalpana are of sheetaveerya, laghuvipaka and are beneficial in digestion of food, maintaining normal functioning of agni.

\section{Results}

Initially Dated 31-10-2020 patient presented with the weight of $86.5 \mathrm{kgs}$ which reduced to $81.1 \mathrm{kgs}$ on the day of discharge. There was $5.4 \mathrm{kgs}$ reduction of weight which shows significant reduction of weight. On 
$18^{\text {th }}$ day patient was discharged on 18-11-2020 and advised to follow same diet schedule with medications and yogas. Follow-up was done after 30 days.

Medications prescribed on discharge

1. Tab Navaka Guggulu 2 BD (A/F)

2. Varunadi Kashaya $(10 \mathrm{ml}$ with warm water $\mathrm{B} / \mathrm{F})$

\section{Discussion}

Ayurveda aims at prevention and promotion of health of a healthy person. It treats diseases on the basis of doshas and dushya which play important role in manifestation of any disease. In this case, patient was diagnosed as a case of sthoulya, predominantly of kapha vata as vitiated doshas and rasa, mamsa, medha as vitiated dushyas.

Ayurveda points out the very basic line of treatment as nidana parivarjana (avoiding the cause) patient had adopted herself to sedentary lifestyle, day sleep, lack of exercises whereas leading to abnormal accumulation of medha dhatu (fat) in the body and landing herself to obesity.

As sthoulya is santarpanyajanya vyadhi the main stream of management is lekhana karma which is treated by Udwartan Karma, followed by Swedana, Virechana, Vyayama, Pathyahara sevana. All parameters because they eliminate Dosha from body and perform the action of samprapti vighatana (breaking of pathogenesis) at cellular level. In this case, we observed significant changes and was advised to follow same diet and yogasanas regularly, follow up is maintained.

\section{Conclusion}

On the basis of signs and symptoms the case of sthoulya was treated with udwartana, virechana followed by pathyahara and yogasanas. Acharya Charaka has classified Sthoulya among Ashtaninditiya purusha. Atisthula may further leads to various other diseases if not treated well. Hence one should follow healthy lifestyle which includes Dinacharya, Rutucharya, Pathya ahara sevana in order to prevent the diseases.

\section{Reference}

1. Kelly T, Yang W, Chen C-S Reynolds K, He J. Global burden of obesity 1431-7. Int J Obes (Lond) 2008 Sep;32(9):1431-7. doi: 10.1038/ ijo.2008.102. Epub 2008 Jul 8. https:// pubmed.ncbi.nlm.nih.gov/18607383/ Dated: 05-08-2021 Time:09:12 IS.

2. https://www.who.int/westernpacific/health-topics/ obesity. dated: 10-08-2021 time: 11:02 IS.

3. Hruby A, Hu.F. The Epidemiology of obesity: A Big Picture. Available from: https:// www.ncbi.nlm.nih.gov/pmc/articles/PMC4859313/ [Accessed:Pharmacoeconomics. $2015 \mathrm{Jul}$; 33(7):673-689]. dated: 09-08-2021 time:10:22 IST.

4. Sharma R.K. and Vaidya Bhagwan Dash, Edition: reprint 2009, Chakrapani on Charaka Samhita, Chowkhambha Sanskrit Series Office Varanasi, Vol 1, ISBN: 81-7080-012-9. p-374-376
5. Yadavji Trikamji, Edition: reprint 2017, Vijayarakshita and Srikantadatta on Madhava Nidana, Published by Chaukhambha Orientalia Varanasi, ISBN :978-81-7637-183-4, p-226.

6. Hruby A, Hu FB. The Epidemiology of Obesity. Pharmacoeconomics. 2015 Jul; 33(7): 673-689. https://www.ncbi.nlm.nih.gov/pmc/articles/ PMC4859313/ dated: 25-07-2021 time:11:05 IST.

7. K.Park, Park's Textbook of Preventive and Social Medicine 21st edition 2011, published by Banarasidas Bhandot Jabalapur, ISBN: 978-81-906079-9-5, p-367.

8. Sharma R.K. and Vaidya Bhagwan Dash, Edition: reprint 2009, Chakrapani on Charaka Samhita,Vol 1,Chowkhambha Sanskrit Series Office Varanasi, ISBN: 81-7080-012-9, p-375-376.

9. Rao Mangalagowri, A Textbook of Swasthavritta, Edition: reprint 2012, Published by Chaukhambha Orientalia Varanasi, p-2-3.

10. Rao Mangalagowri, A Textbook of Swasthavritta, Edition: reprint 2012, Published by Chaukhambha Orientalia Varanasi, p-2-3.

11. BMI chart for obesity. WHO.

12. https://www.euro.who.int/en/health-topics/diseaseprevention/nutrition/a-healthy-lifestyle/body-massindex-bmi. dated: 21-06-2021 time: 10:09 IST.

13. Nadkarni Shailesh, Arogyamandir Medhorog visheshank Edition: March 2008, published by Shree dhootapapeshwar Ltd, p-1-8.

14. Lohit B.A, Textbook on Panchakarma 1st edition: 2016, Vol-1, chapter-2, ISBN:978-81-7637-365-4. Chaukhamba orientalia, Varanasi, p-107-08.

15. Santra Ramen et al. A comparative clinical evaluation of Ayurvedic diet plan and standard diet plan in Sthoulya (Obesity). Int. J.Res. Ayurveda Pharm. 2013; 4(5):680-684 http://dx.doi.org/ 10.7897/2277-4343.04510 dated: 25-07-2021 time: 11:019 IST.

16. Hiremath S.G. A textbook of Bhaishajya Kalpana, edition: 2000, IBH prakashana, Bangalore, p-281.

17. Murthy KRS. Bhavaprakash of Bhavamishra. Edition: 2004, Chaukhamba Krishnadas academy Varanasi, p-465.

18. Rao Mangalagowri. The Essence of Yoga, 1st edition: 2011, Published by Chaukhambha orientalia, Varanasi, ISBN: 978-81-7637-250-3, p-104-115.

19. Mahesh Raju B et al, Management of Obesity (Sthoulya) A Success Story - A Case Study. International Ayurvedic Medical Journal \{online\} 2017 \{cited April, 2017\} Available from: http:// www.iamj.in/posts/images/upload/1335_1344.pdf dated:27-07-2021 time: 09:16 IST.

20. Deshpande Harish et al. Ayurvedic Therapy in Morbid Obesity- A Case Study. Punarnav sep-oct 2014: vol: 2 issues: 5.

21. Mandalkar Pramod et al. A Clinical Study Of Tryushnadhya Lauha Vati In The Management Of Sthaulya W.S.R. To Obesity. IAMJ: Volume 3; Issue 11; November-2015. http://www.iamj.in/posts/ 2015/images/upload/2286_2293.pdf dated: 23-07-2021 time: 10:26 IST. 
22. Jadavji Trikamji Acharya and Narayan Ram Acharya, Edition: 2002, Nibanda Samgraha Commentary of Dalhana on Sushruta Samhita, Chaukamba Surabharati Prakashana, Varanasi, $\mathrm{p}-227$.

23. K R Srikanthamurthy Edition:2007. Vagbhata on Ashtanga HridayaChaukambha Krishnadas Academy, Varanasi, p-202-203.

24. Sharma Ram Karan and Dash V B, Edition:2011, Agnivesha on Charaka samhita, chowkamba sanskrita samsthana, Varanasi, p- 468-469.
25. Gupta Deepak K, et al, A Clinical Study of Lekhana Karma of Varunadi Kashaya in Comparison with Medohara Guggul in The Management Of Sthoulya (Obesity).IAMJ: Volume 4; Issue 05; May-2016. http://www.iamj.in/posts/images/upload/ 943_948.pdf dated: 29-07-2021 time: 10:22 IST.

26. Lohit B.A, Textbook on Panchakarma 1st edition: 2016, Vol-1, chapter-2, Chaukhamba orientalia, Varanasi, ISBN:978-81-7637-365-4, p-107-08. 